University of Wollongong

Research Online

Faculty of Business - Papers (Archive)

Faculty of Business and Law

2013

Whither 'training and development' in Vietnam?: learning from United States and Japanese MNCs' practice

Anne Cox

University of Wollongong, avo@uow.edu.au

Malcolm Warner

University of Cambridge

Follow this and additional works at: https://ro.uow.edu.au/buspapers

Part of the Business Commons

Research Online is the open access institutional repository for the University of Wollongong. For further information contact the UOW Library: research-pubs@uow.edu.au 


\title{
Whither 'training and development' in Vietnam?: learning from United States and Japanese MNCs' practice
}

\begin{abstract}
This paper focuses on training and development (T\&D) policies and practices to explore how multinational companies (MNCs) localise their human resources within their subsidiaries in a developing country. It uses qualitative research methods to examine three US and three Japanese MNCs operating in the automotive and fast-moving consumer goods (FMCG) industry in Vietnam. The paper identifies both home- and host-country effects as significant factors in the transfer of MNCs' T\&D policies and practices. Clear home-country effects are evident in rigorous attempts of both US and Japanese MNCs to transfer and implement formalised and centrally controlled training programs. Host-country effects manifest themselves in the instability of the institutional environment, weak associations among employers' groups, and fragmented bargaining practices that encourage employer and employee opportunism, particularly 'poaching' and 'job-hopping'. These lead to MNCs' hesitation to invest in T\&D, and the lack of job rotation and a tendency to train 'specialists' rather than 'generalists' in the Japanese firms. The paper also discusses the interaction of foreign owned and indigenous firms in a very tight labour market at the highly skilled end that results in a 'brain drain' phenomenon on human resource development (HRD).
\end{abstract}

\section{Keywords}

learning, united, states, japanese, mncs, practice, whither, development, training, vietnam

\section{Disciplines}

Business

\section{Publication Details}

Cox, A. \& Warner, M. (2013). Whither 'training and development' in Vietnam?: learning from United States and Japanese MNCs' practice. Asia Pacific Journal of Human Resources, 51 (2), 175-192. 
WHITHER 'TRAINING AND DEVELOPMENT' IN VIETNAM? : LEARNING FROM US AND JAPANESE MNCs' PRACTICE

*Anne Cox, Faculty of Commerce, University of Wollongong, Wollongong, NSW, Australia and

Malcolm Warner, Judge Business School, University of Cambridge, Cambridge, UK

[*corresponding author: Anne Cox, avo@uow.edu.au] 


\section{ABSTRACT:}

This paper focuses on the training and development $(T \& D)$ policies and practices to explore how multinational companies (MNCs) localize their human resources within their subsidiaries in a developing country. It uses qualitative research methods to examine three US and three Japanese MNCs operating in the automotive and fast moving consumer goods (FMCG) industry in Vietnam. The paper identifies both home and host country effects as significant factors in the transfer of MNCs'T\&D policies and practices. Clear home country effects are evident in rigorous attempts of both US and Japanese MNCs to transfer and implement formalized and centrally controlled training program. Host-country effects manifest themselves in the instability of the institutional environment, weak associations amongst employers' groups and fragmented bargaining practices that encourage employer and employee opportunism, particularly 'poaching' and 'job-hopping'. These lead to MNCs' hesitation to invest in $T \& D$, and the lack of job rotation and a tendency to train 'specialists' rather than 'generalists' in the Japanese firms. The paper also discusses the interaction of foreign invested and indigenous firms in a very tight labour market at the highly skilled end that results in brain drain and spillover effect phenomena on HRD.

\section{KEYWORDS:}

HRD, HRM, Japanese MNCs, training and development, Vietnam, US MNCs.

\section{INTRODUCTION}

This paper deals with training and development (T\&D) in a developing country and focuses in particular on this activity in Vietnam. It attempts to learn from US and Japanese human resource management (HRM), and how these multinational corporations' (MNCs) practices have been exemplified in the host-country. The influence of foreign firms' HRD (Human 
Resource Development) practices are examined in the context of the globalization process (see Ohmae 1990 and onwards) which has suggested that distinct national economies are subsumed into region-states' and firms' convergent practices (Rowley and Benson 2002, Bartlett and Goshal 1989; Warner 2011). On the other hand, others point to the worldeconomy as characterized by relatively distinct national economies (see Harzing and Noorderhaven 2009, Rowley and Benson 2002). They suggest that multinationals (MNCs) remain primarily rooted to their country-of-origin nation (Ferner and Quintanilla 1998) but may be faced with a 'think global', 'act local' paradox (Harzing and Noorderhaven 2009, Rowley and Benson 2002, Smale 2008).

Aiming in this direction, the paper at hand addresses the transfer of training and development policies and practices in US and Japanese MNCs in Vietnam. It asks the following research questions: 1) what is the extent to which MNCs are influenced by their home experience regarding training and development policies and practices? 2) how far are patterns of behaviour at home refracted through the lens of host institutional constraints and requirements in their foreign subsidiaries in the process of transfer?; and 3) how distinctly do MNCs of different country-of-origins interact and influence the HR operations of each other and their influence on the shaping of HR practices of indigenous firms?

Given its importance, we selected T\&D as the generic area of investigation, in order to advance further both theoretical and pragmatic insights into the topic. It not only is the one HR area that bears strong imprints of home-country but also one that potentially contains conflict of interests between MNCs and host- countries, especially developing ones (see Dowling et al 1999, Smith and Meiksins 1995). We believe that this approach will be the most intellectually fruitful one. 
We have structured the paper as follows. The literature review is followed by sections on the research methodology. The empirical findings are then presented within three categories, namely the extent and nature of training, training-programs and the comprehensiveness of training-programs. This section is followed by a discussion and conclusions section.

\section{LITERATURE REVIEW}

In our literature review, we have concentrated on two distinct strands of the literature. These are: 1) the transfer of HRM practices across borders, on which a great deal has been written and which we will therefore only report on in summary; and 2) MNCs' training and development policies and practices in Vietnam, which is less well-covered, on which we will report in greater detail.

\section{The transfer of HRM practices across borders}

Comparative institutionalism theory has been widely used to study the diffusion and transfer of organizational practices across countries. Operating in more than one country, MNCs confront a multitude of different and possibly conflicting institutional pressures (Ferner and Quintanilla, 1998; Harzing and Noorderhaven 2009). Since it is vital for MNCs to establish and maintain organizational legality in all their host environments, they need to conform to the legal environment, particularly to labour issues, as well as the cultural environment. Furthermore, as argued by Birkinshaw and Hood (1998), subsidiaries possess their own capabilities and resources such as consumption market, resources, and efficiency, which are desirable to the parent company. MNCs therefore are under pressure to adopt local practices in the host countries (Kostova and Zaheer, 1999; Ghoshal and Barlett, 1988; Taylor et al., 1996). This 'host-country effect' which Scott (2001) conceptualizes as the three pillars of 
institutional processes - regulatory, cognitive and normative - places a myriad of differing institutional demands on MNCs (Harzing and Noorderhaven 2009, Ferner and Quintanilla 1998) and represent the most significant constraints on the 'context generalizability' of HRM practices (Ferner 1994, Geppert and Williams 2006, Whitley 2000).

On the other hand, there is evidence to support the thesis that country-of-origin exerts a distinctive influence on how HR is managed in MNCs (see Bjorkman and Lu, 2001; Yan, 2003; Faulkner et al., 2002; Gunnigle et al., 2002). With headquarters (HQs) being embedded in the institutional environment of the home-country, these features are in-built into each MNC corporate identity (Ferner et al 2005). These country-oforigin effects, in turn, create additional pressure for the subsidiary to maintain internal legitimacy within the MNC's operations (Kostova and Zaheer 1999), shaping its international orientation, particularly with regard to structure, strategy and HR practices (Ferner and Quintanilla, 1998; Noorderhaven and Harzing 2003).

Kostova and Zaheer (1999) argue that each subsidiary of the MNC is faced with the task of establishing and maintaining both external legitimacy in its host environment and internal legitimacy within the MNC. Within the host environment, MNCs may maintain external legitimacy by becoming 'isomorphic' with their multiple, institutional environments through various negotiation-processes which may lead to 'adaptation' or 'local hybridization' of practices to suit local demands (Poutsma, Ligthart and Veersma 2006). Some researchers have argued that the 'institutional pressures' that necessitate both legal- and cultural-conformity (Vo and Rowley 2010) are often more compelling than pressures arising from the country-of-origin (Gunnigle et al, 2002). In this scenario, headquarters may place less emphasis on transferring HRM practices from the parent corporation to the subsidiary, than on gaining 
knowledge and/ or supporting the practices of subsidiaries. Conversely, Bjorkman et al. (2007) suggest that those MNC subsidiaries that choose to transfer and implement HRM practices that are considered particularly suitable for their distinct operations. Similarly, the utilization of organizational capabilities worldwide offers competitive advantage for the MNC (Nohria and Ghoshal 1997). In any case, the pattern of oscillation between centralized-control and subsidiary-autonomy is noteworthy (Ferner et al 2004; Geppert and Williams, 2006).

\section{A focus on MNCs' training and development policies and practices in Vietnam}

This section discusses how the transfer of training and development practices is influenced and is shaped by varying factors in host-country systems.

\section{Home-country influences}

The US business system can be categorized as a liberal market economy (Ferner 2000, Ferner et al 2001, Hall and Soskice 2001) where economic activities are chiefly regulated by market forces (Clarke and Almond 2004; Farndale et al 2008). Significant changes to the US financial system in the 1980s and 1990s saw a strong surge of 'shareholder value' ideology and an emphasis on 'short-termism' (O'Sullivan, 2000: 155). Historically, market imperatives encouraged the development of centralized management control systems (Clarke and Almond 2004).

The scope possessed by US firms to transfer their practices to host environments is a recurring feature of the literature, and is conceptualized as the Anglo-Saxonization of HRM practices across national borders (Farndale et al 2008). Much research attention has been 
placed on areas of distinctiveness, most notably on strategic HRM (Doz and Prahalad 1984, Pudelko and Harzing 2007; Schuler and Jackson 2005). Whilst the 'short-termism' that characterizes the American model may limit long-term stable relations with employees (O’Sullivan 2000; Hollingsworth 1997) research conducted on North American MNCs suggest that they provide good training for expatriate managers, as well as learning and opportunities for local managers. The focus is driven primarily by the goal of human capital building through targeted training initiatives (Banks 2004, Giardini, Kabst and Muller-Camen 2005). There is also support for a positive role for higher levels of work-related training for more educated employees (Van Smoorenburg and Van der Velden 2000; Tan and LopezAcevedo 2003).

On the other hand, Whitley (1999) classifies Japan as a 'collaborative national business system'; whilst Hall and Soskice (2001) categorize it as a 'coordinated market economy'; and Ahmadjian and Robbins (2005) liken its business environment to a 'community'. These classifications both emphasize that 'institutional cooperation' (Dore 1987, Elgar and Smith 1994, Orru 1997, Yu and Meyer-Ohle 2008) is the key feature of Japanese capitalism (McGuire and Dow 2003).

The Japanese HRM system develops long-term strategies. The stereotype of HRM practices in Japan, characterized by the three pillars: lifetime employment, a seniority-based wage structure, and enterprise unionism, is well-known. The normative pattern in large Japanese firms nurtures long-term employment, internal skill formation and the development of the internal labour-market (Ahmadjian and Robbins 2005). Japanese large firms invest extensively in training. The emphasis on job-rotation creates an environment in which an employee becomes a 'generalist', rather than a 'specialist' (Pucik and Hatvany 1983, Kono and Clegg 2001). 
In 1986, the Vietnamese introduced a reform program, known as Doi Moi, to liberalize the economy from a socialist to a more market one (see Collins 2009). In 2010, Vietnam's Gross National Income per capita was \$US 2,910, classifying Vietnam as a 'lower middle-income' economy $(\$ 1,006$ to $\$ 3,975$ ) (World Bank 2011). Meanwhile, FDI is one of the most essential sources of investment (World Bank 2005, 2011). The sub-systems (financial, educational and training systems, network of business associations, and system of HRM and so on) remain constantly under pressure of change and innovation (Vo 2009).

Since Doi Moi, the Vietnamese education has undergone significant renovation and achieved important results such as increased enrollment, diversification of delivery modes, improved school infrastructure, etc. (MOET, 2006). However, even though mass education level is high, Vietnam has a scarcity of highly-skilled labour. Around 96 per cent of the Vietnamese population is literate and 80 per cent went to primary school. But, the skilled-labour force accounts for only 8 per cent of the total labour-force (MOLISA 2002, p. 7). Hayden and Thiep (2007, p. 74) state that only 10 per cent participates in the higher-education system (Truong and Swierczek 2009). Furthermore, there is a chronic mismatch between the output of the education-system and the input of corporations (Duoc and Metzger 2007, Hargreaves et al. 2001, MOET 1997, MPI 2006).

There are several reasons for this 'training- gap'. First, there is resistance to vocational training and a preference for university (Beresford 1988). Second, graduates lack practical experience and skills and fail to meet employers' requirements (Duoc and Metzger 2007, Vo 2009). The curricula are not related to practical training-needs (Hargreaves et al. 2001), Thang and Quang (2007) suggest that 80 per cent of students need to be re-trained before assigned to work. Third, labour-market data in Vietnam is scarce, so employers are not well- 
informed (Duong and Morgan 2001). This state of affairs in reality is, however, not that dissimilar from that found in China today (see Warner and Goodall 2009).

Training-studies focus on different sectors in Vietnam (McDaniel et al 1999), including small and medium businesses (SMEs), state owned enterprises (SOEs) and MNCs and confirm a positive relationship between training-investment and organizational performance (see Gieb 1999, King-Kauanui et al. 2006, Thang and Buyens 2008). Thang and Quang (2007) stated that whilst most Vietnamese organizations are aware of the link between training and performance, they often lack resources to implement it. This fact leaves employees with little option but to seek self-development through vocational schools, colleges and universities (Vo 2009).

In the context of SMEs, King-Kauanui et al.'s (2006) research on training-initiatives in 200 Vietnamese manufacturing corporations determined a positive correlation between higher levels of spending on training and higher levels of SME performance. Nevertheless, whilst most of the SMEs participating in the study provide some form of training for their employees, it is largely informal, a common feature of SMEs. Furthermore, SME's put limited resources into training. Thang and Quang (2007) indicate poor outcomes due to weak HR resources.

Research suggests that MNCs invest more into training initiatives than either SMEs or SOEs (Friedman 2004, Thang and Quang 2007). According to Thang and Quang (2007), foreign investors understand lack of skills and qualifications in the labour-market and make training a priority. Gieb (1999) in interviews of Vietnamese managers of US subsidiaries in Vietnam found that it used as a key strategic management tool. Joint-ventures and foreign-owned corporations offer training facilities and highly skilled expatriates to help (Thang and Quang 
2007, Thang and Buyen 2008). Training may thus be considered as a means of supporting organizational strategy.

\section{METHODOLOGY}

To elucidate the above linkages, we utilize a case-study strategy in this study due to the need to examine in detail the employment practices of corporations in this domain (see Noble 1997). For the purposes of this study, a qualitative methodology represents an appropriate means of capturing such detail (Yin 2009). We thus conducted interviews in-depth at six MNCs, three of which are Japanese MNCs and another three are US MNCs in automotive and fast-moving consumer good (FMCG) industries. In this research, multi-case studies are expected to effectively represent American and Japanese companies operating in these two industries. It is important to have more than one case study in order to compare/ contrast cases and test the relevance of arguments in different contexts. As Eisenhardt (1989) argues, the strength of a multiple case study method of research comprising over five cases is the potential for a higher level of applicability of findings generated, as it enables one to test explanations and models through a 'replication logic' across cases.

The selection of samples of companies is, clearly, a crucial decision. Not only has the sample to be of US/ Japanese nationalities in the automotive and FMCG industry, it has to be feasible within fixed constraints of time, finance, and most importantly, accessibility. Some criteria govern the choice of firms: (1) Priority is given to companies that have been in operation for a longer time. The purpose is to investigate their HRM in general and T\&D activities in the longest possible time span; (2) Priority is also given to MNCs that have a larger number of employees, where the 'clash' between the practices emanating from the US / Japanese business system and the emerging Vietnamese system can be seen; and (3) The selected firms should be relatively comparable in terms of their investment capital, capacity and number of employees. With these criteria, six companies were chosen, with three companies in each industry. The investigated corporations (see Table 1) are coded as follows:

- US Auto, JP Auto1 and JP Auto2

- US FMCG1, USFMCG2 and JP FMCG 
INSERT TABLE 1 ABOUT HERE

Table 1: Description of Firms in the Study.

\begin{tabular}{|l|l|l|l|l|l|}
\hline NATATIONALITY & FIRM & PRODUCTION & AGE/YR & LOCATE & SIZE* \\
\hline US & US Auto & Car Assembly & $>10$ & North & Med. \\
\hline JP & JP Auto1 & Car Assembly & $>10$ & North & Med. \\
\hline US & JP Auto2 & Motorcycle Assembly & $>10$ & North & Large \\
\hline US & US Production & Personal Hygiene & $>10$ & South & Small \\
\hline JP & US & Personal Care & $>10$ & South & Large \\
\hline
\end{tabular}

NOTE: Size is based on no of employees; Small $=>250$, Med $=250-500 ;$ Large $=>500$.

The study took place during a six-year period from 2001 to 2007 and included three fieldwork trips in Vietnam, totalling more than nine months. Multiple interviews (see Table 2) were held with key informants. The two groups comprised of: 1) internal interviewees, including the management of corporations and employees on the shopfloor (workplace-level); and 2) outside interviewees, including central and local-government authorities (macrolevel). With the first group: corporation profile and structure, training and development policies and practices, constraints and opportunities offered by the Vietnamese context and the mechanisms the corporation had developed to cope with local situations. Interviews were also conducted with government officials at national and local levels.

The results of interviews in Vietnam were enhanced by documentary analysis and interviews 
held at (or questionnaires sent to) the headquarters of the studied corporations. The main purpose of the interview/questionnaire conducted at global/regional level was to identify which international HRM policies were present at this level and to what extent the corporations expected them to be transferred to Vietnam.

INSERT TABLE 2 ABOUT HERE.

Table 2: Interview Distribution of the Case Studies

\begin{tabular}{|c|c|c|c|c|}
\hline Company & Interviews & Managers & Employees & Union \\
\hline US Auto & 31 & 20 & 9 & 2 \\
\hline JP Auto1 & 14 & 5 & 7 & 2 \\
\hline JP Auto2 & 17 & 8 & 7 & 2 \\
\hline US FMCG1 & 16 & 8 & 6 & 1 \\
\hline US FMCG2 & 11 & 6 & 8 & \\
\hline JP FMCG3 & 12 & 3 & & \\
\hline Total & 101 & & & \\
\hline interviews \\
conducted \\
workplace
\end{tabular}

The processing of fieldwork data relied mainly on an explanation building technique and within-case and cross-case synthesis. Such an approach is a result of a series of iterations, 
where initial theoretical propositions are compared with initial findings and revised, probably several times, as data from all cases are collected (Yin, 2003). Therefore, the final explanation may not have been fully stipulated at the beginning of the study. In this research, the initial literature review enabled the researchers to progressively gain 'theoretical sensitivity' (Glaser, 1978 cited in Maxwell, 1996: 77) and was used to generate themes and issues for the first fieldwork. After the first fieldwork, when the general picture of the cases had emerged, the research questions were re-defined, new themes were recognised, the focuses were narrowed down, and gaps left unintentionally were identified. All this was taken into consideration in the second fieldwork. Moreover, preliminary findings were discussed with the companies during the second and third fieldwork. It was useful in relation to the validity of the data because it enabled the researcher to get feedback from the companies on how plausible the emerging interpretation was.

The analysis has two key steps: within-case analysis and cross-case analysis. Within-case analysis involved brief case study write-ups for each company. The idea here was to become familiar with each case as a stand-alone entity. This process allowed the distinctive patterns of each case to emerge before generalising patterns across cases. The next step was to analyse cross-cases. In order to manage the immense amount of data collected and to avoid 'data asphyxiation' (Pettigrew, 1990: 281), it was decided to index all the collected information and then organize and structure them by main themes (similar to the themes in the interviewing questions). This was coupled with within-case analysis, to make sure that the information/ evidence placed within each theme was not unrelated to the company as a whole and was able to reflect the characteristics of the company. In this step, within theme similarities and differences were sought. Once general patterns and differences were identified and tentative explanations elaborated, these were compared with the evidence of each other case, through a 'replication logic', which made it possible to extend them, qualify them or eventually drop them (Eisenhardt, 1989). 


\section{EMPIRICAL FINDINGS}

This section looks at training and development in the US and Japanese MNCs under three categories, namely 1) the extent and nature of training, 2) the training-programs and 3) the scope of training-programs.

\section{The extent and nature of training}

In the automotive industry, training and development is formalized and centrally controlled, especially during the early years. The subsidiaries' training activities are monitored and backed up by experts from HQs or other countries who might drop by for irregular quick 'check and fix' sessions, followed by an annual full-audit. Training is one of the ten components of the US Auto-Production System, which have been audited annually on a global scaled score ${ }^{1}$. US Auto's Production Manager commented that 'T\&D is one of the most crucial dimensions of quality-control from HQs'. The use of 'coercive comparisons' (Edwards et al 1993, Ferner and Edwards, 1995) tightens the co-ordination process from HQ and limits subsidiaries from diverging themselves from the global mould. Similarly, training is central in JP Auto1's Production-System, which is audited annually on a global scaled score. Training and development courses offered cover both production-related and managerial- skills. Vietnamese managers are sent to the HQs or other overseas subsidiaries to attend short-courses and training-programs (Collins 2009) as may be the case with American MNCs operating in China (see Warner and Goodall 2009).

On the other hand, in FMCG industry, training-practices diverge. US firms invest more on T\&D - than their Japanese counterparts. However, more vigorous attempts to increase the quality of managerial-staff - but little effort is put on blue-collar workers, citing the reason

\footnotetext{
${ }^{1}$ US AutoProduction System's ten components consist of managing, training, work groups, administration, machine, safety, total inventory, manufacturing, engineering design and material flow.
} 
that the simplicity of the production-process requires very little training. Line-workers are only trained for basic production-techniques on their induction-program. US FMCG2's Marketing Manager said:

'There is a huge difference between training provided to managers, especially higher level ones, and that to employee. Middle level managers are often sent to attend short courses overseas and courses provided by local training providers. Moreover, the company often invites foreign trainers to the main office to train managers on special management skills topics... On the contrary, jobs at the factory require simple manual skills. On-the-job training is sufficient.'

In the studied Japanese firms, training is production- focused and based on an ad hoc basis (production-needs and the availability and convenient timing of courses offered by the corporation or outside training providers). The Japanese FMCG human resources manager interviewed received no preparatory training to equip him to take on the challenges of the post and needed hard self-study. Training mainly focuses on technical-workers and involves learning through the assistance and supervision of a senior- employee, normally the production-line leader, who helps the trainee learn skills applicable to the production-lines.

Interview data reveals that the US firms tend to invest more in training for their managers than Japanese firms do. A lower level of investment is recorded in FMCG industry compared to automotive one (see Table 3).

INSERT TABLE 3 ABOUT HERE

Table 3 Training Provided to Managerial Staff

\begin{tabular}{|l|l|l|}
\hline Company & Training time/working time & Training expenditure/employee (\$US) \\
\hline
\end{tabular}




\begin{tabular}{|l|l|l|}
\hline US Auto & approximately 10\% & $>300$ \\
\hline JP Auto1 & $8 \%$ & 167 \\
\hline JP Auto2 & $7 \%$ & 141 \\
\hline US FMCG1 & $5-6 \%$ & $>200$ \\
\hline US FMCG2 & $6 \%$ & about 250 \\
\hline JP FMCG3 & $3 \%$ & 64 \\
\hline
\end{tabular}

Source: Company data and interviews.

\section{Training-programs}

As a rule, management-training-programs in Vietnam must start with the very basics of business-education in their curriculum. Both American and Japanese employers provide broad-based foundation training for their staff as a basis for further training which is provided afterwards. The HR Manager of JP Auto1 stated that:

'Our motto is "recruit for attitude and train for the skills". We all know the shortcomings of our university education - students are well-versed with abstract subjects, such as communist philosophies, history of economies, etc. but they do not have what really matters at workplace- practical skills...We have complete programs to build up our employees' skills almost from scratch.'

Similarly, US Auto has implemented a 'learning-tree' training scheme with roots (basic business skills) (stage 1), trunks (functional-skills and advanced business-skills) (stage 2) and leaves (management- and leadership- skills) (stage 3). In the first stage of its program, 100 percent of staff is required to participate in basic business-skills training to ensure that all employees have basic business-awareness and speak the same business-language. In the next stages, the corporation seeks to develop potential managers only. In the same way, JP Auto2 
develops a model of 'Six Steps' on-the-job training which covers the corporation's whole workforce. Step one is for the lowest-level of employees and step six is for managerial-staff members. Six Steps aim to upgrade employees-skills and knowledge from the very basic level, such as to complete routine repeatable jobs under detailed-instructions and regularsupervision (Step one) to use own judgments and creativity to complete tasks with limited supervision (Step 6). An interviewed worker at this company proudly revealed to the researchers that he has proceeded to Step 4 and that it has taken him years to reach there. This interviewee, together with others, confirmed that although they have worked elsewhere before joining the companies, they felt like a 'white sheet of paper' when they started their intensive training programs in the companies.

Managers and professional/technical staff tend to undergo more external training-programs than internal. When internal training mode was used, it was mainly on-the-job training for clerical-, sales- and production-employees. Employees can choose the courses to suit their personal development-needs or take them as a compulsory requirement for their current/ new posts. Many of these programs are taught overseas or led by foreign experts so that Vietnamese managers can gain international experience. US firms offer 'shadowing opportunities', where potential persons follow managers in the US full-time. A top manager at US FMCG1 commented that:

'The shadowing opportunities that I have had were incredible learning experience for me. Not only I have learnt certain knowledge, but most importantly I also learnt from expatriate managers their working styles, the way they handle problems, their leadership styles. Through them, I also met different people and made precious contacts that have been so helpful to my current work.'

US Auto1's HR Manager also commented that 
'Only by obtaining training at this high level could Vietnamese managers are equipped with the necessary knowledge and prepare themselves for future opportunity to take up key positions in the company that currently are occupied by expatriate managers'.

One of the more advanced approaches adopted by the studied MNCs is e-learning. This medium uses corporation's networks to deliver training-courses to employees and thus allows Vietnamese employees to get access to a well of knowledge available to the corporations' global-workforce. However, as a type of education where the medium of instruction is computer-technology without personal-interaction, e-learning has certain weaknesses, such as the lack of instructor-interaction (Bank 2004). In the Vietnamese context, some interviewed managers point out that e-learning might not be optimal as the workforce might not have a strong knowledge-platform to make a good use of the corporation's global resources.

Corporations in automotive industry also introduced a relatively new training concept, especially in Vietnam, namely 'blended-learning'. This aims to overcome the inadequacies that evolve from e-learning, with two or more methods for delivering training (Bersin 2004, Mackay and Stockpot 2006). A popular style of a blended-learning program involves combining both e-learning and manager-led on-the-job training. This style of training is popular with Vietnamese employees and to be more efficient than a singular classroom or elearning program. Blended-learning also transfers the responsibility of learning to the individual, provides more immediate feedback from the supervisor and offers greater flexibility in delivery (De Jong and Versloot 1999).

US corporations focus on cross-culturally based policies, such as a minimum of one week per-year of training and development for each manager, an in-house top managementprogram and management forum, where participants are executives from all regions. The 
management forum in particular is a popular training tool to Vietnamese managers, who have good control of English. An interviewed manager at US Auto said:

'This presents an excellent opportunity to 'learn from a well of knowledge and interact with other employees from different countries.'

In the same line of thought, an interviewed manager at US FMCG2 point out that:

'I have learnt a lot from other managers in other countries. If we have a problem at work, we can post an email on the forum and ask for advice from those that have experienced the same or similar problems. People from over the world might reply and I often feel overwhelmed at how enthusiastic they are to help.'

By contrast, Japanese corporations encourage employees to identify themselves within the corporation by emphasizing its philosophy. In addition, e-forums and e-networks contribute to create a global culture and transfer 'soft skills'.

In the Vietnamese market, corporations are faced with a dilemma - they could spend a fortune on training their management staff - only to see them leaving the corporation (newlyequipped with skills which make them more desirable in the market) for higher- paying employers, in many cases a competitor-corporation. JP FMCG's HR Manager complained that:

"It is a real headache! We train them and they leave. But if we do not train them, they leave too! Or worse, they stay because they think no one else might want them!'

Preventative strategies have been applied to keep trained- managers with the corporations and reduce a 'regretted' turnover-rate. US Auto, US FMCG1 and US FMCG2 provide training-programs and/ or financial support to managers' self-education only on the condition 
that they will be bound by a legal contract with the corporation to stay for at least 5 years after. JP Auto1, JP Auto2 offers highly firm-specific training-courses (such as the corporation's New Circle Leader, Training Within Industry, Corporation Philosophy and so on), which improve promotion internally but are of little help for these persons in seeking jobs elsewhere. No 'normal' degree or certificate has ever been given. The corporations thus limit the ability of their employees from using the knowledge to advance their positions elsewhere.

\section{Comprehensiveness of training-programs}

In general, training-programs in the studied Japanese firms heavily focus on technical knowledge and neglect people- management skills, whilst a more balanced approach can be seen in the US firms (on Chinese practice, see Warner and Goodall 2009). Well-structured and organized training-systems are evident in the US firms. Training needs are identified as a cycle which requires close cooperation between supervisors and subordinates. Managers' training needs are discussed annually, based on three factors: the corporation business plan, the departmental improvement-goals and individual's personal-needs. Training results are monitored to allow a continuous improvement training-cycle.

A second feature which the four US corporations share is their commitment to job-rotation. The arrangement for this is fairly formal at least on paper, although results vary significantly. Managers are required to select the area of expertise they wish to move to, whilst supervisors are responsible for providing them with training for new jobs. US FMCG1 reports no difficulty in inter-functional mobility; they report 25 percent of their management qualified for the second-phase. 
Even so, US Auto states that 'meaningful rotation is rather limited at the top levels.' Due to the workload and endeavor for high-performance ratings, sections/ departments/ firms tend to resist rotation. Nonetheless, US corporations develop interdisciplinary skills on a localized basis.

By contrast, in most Japanese subsidiaries in Vietnam, job-rotation is not popular. Even though some limited movement has been recorded, for example staff went from HRM to PR departments, the movement is for the convenience of the corporation rather than as an intended rotation. Doing so for workers in production-lines is more popular. Vietnamese managers in these corporations are often seen as stuck in narrow specialisms. JP Auto2 serves here as an example. An ethnocentric approach in global staffing-strategy restrains JP Auto2 from developing their local-managements. The 'Rotation Rule', which requires a person not to remain longer than 3 years at their post, is applied to senior levels only. In effect, this preempts rotation for local managers. JP Auto2 shows a strong trend towards developing Vietnamese managerial 'specialists' rather than 'generalists'. These practices are totally in contrast with what is recorded back in Japan.

\section{DISCUSSION AND CONCLUSIONS}

The aim of this research is to investigate three key areas: 1) the extent of home country influence on the transfer of T\&D policies and practices; 2) how host country effects influence this process; and 3) how MNCs interact with each other and the influence MNCs have on the shaping of HR practices of indigenous firms.

Regarding home-country influences, findings from this study confirm that the distinctiveness of the US and Japanese models of training for local managerial staff-practices are refracted 
and diffused in the transfer process. They also give weight to the argument that the 'ethnocentric' approach utilized by HQs of both Japanese and US MNCs (Harry and Nakajima, 2007) may not be applicable to all industry sectors. More comprehensive training initiatives were evident in the automotive- than in the FMCG-industries (cf., Rosenzweig and Singh 1991).

In the case of Japanese MNCs, key elements of the typical Japanese training-system, such as job-rotation and managers' training towards a generalist career-path (Ouchi 1981, Pucik 1984) were not present in the Vietnamese subsidiaries, although interviews with Japanese expatriate managers and questionnaires sent to the studied-firms' HQs confirmed these practices were exant in Japan. One may argue that MNCs themselves may consider the transfer of HRM to be unnecessary for successful operations in Vietnam.

The findings of this study also provide evidence to support the characterization of Vietnam as a weak or permissive host-business system (see for example, Whitley 1992, Collins 2009). Yet a host-country may still poses constraints that inhibit MNCs' ability to maintain distinct HRM practices. Such hindering factors do not come solely from a wall of legislation, but rather from weaknesses that exist in the system. Weak associations that exist amongst employers' groups and fragmented bargaining-practices may encourage employer- and employee-opportunism, particularly in the way of 'poaching' and 'job-hopping'. Findings from this study suggest blocking-strategies being used by both US and Japanese MNCs as a means of coping with these institutional weaknesses. US MNCs sign binding-agreements committing managers to their firms for at least 5 years as a prerequisite for the provision of training programs, whilst Japanese MNCs provide highly firm-specific experience.

Due to weaknesses in the educational and vocational training systems in Vietnam, there is increasing expectation placed on MNCs to improve the skills of the existing labour-market 
(see Thang and Quang 2007). The onus for introducing training- efforts to upgrade the quality of the workforce has progressively shifted to the MNCs (Gieb, 1999) and these may represent a necessary strategic investment (Thang and Buyens, 2008). Furthermore, the Vietnamese Labour Law emphasizes the importance of on-the-job training and stipulates that an employer 'shall be responsible for arranging improvement of the trade skills of its employees and for re-training employees who are assigned to other jobs within the enterprise' (Vietnamese Labour Code, 2002, article 23). Incentives are offered to enterprises in the form of tax exemption to encourage in-house training for their employees (Vietnamese Education Law 1998, Labour Law 1992). In theory, the law provides scope for the integration of training into business strategies and HRM systems. However, this study points out that MNCs are not necessarily willing to shoulder these responsibilities, as in the case of the FMCG industry.

Last but not least, this study demonstrates an interaction between MNCs of different home countries in a tight labour-market. At the highly-skilled end of the labour-market, MNCs are in the position where they have to offer training-opportunities for their local staff-members in order to retain them. All interviewed Vietnamese managers acknowledge that the opportunities for further development in the form of 'foreign invested corporations' training and overseas-exposure are amongst one of the strongest influences in their decision to work for them.

As far as the 'brain-drain' is concerned, turnover- rates for senior levels in Japanese firms are much higher than in US firms. In the automotive-industry, it has been around 7-9 percent in US, compared to 22-25 percent in Japanese firms. Meanwhile, in the FMCG industry, turnover-rates are consistently lower, but JP FMCG also recorded higher turnover- rates of 15 percent - compared to 9-13 percent - in their US counterparts. Interviews conducted by JP 
Auto2 and JP FMCG vis-à-vis 'regretted' turnover show that the most cited reason for leaving the corporations was the perceived lack of training or the feeling of receiving fewer opportunities.

The authors have seen evidence of a 'brain-flow' from the Japanese firms and indigenous firms to US firm but no case of movement in the opposite direction. The production-manager of US Auto could easily name top/key performers in JP Auto1 or JP Auto2. The competition for high-quality staff is fierce and poaching is popular in a tight labour-market. The production- manager of US Auto can name top/key performers in JP Auto1 or JP Auto2. Highly-experienced painters of SOEs in the automotive- industry (such as Song Cong Diesel Corporation, Machinery Spareparts Corporation No.1, Co Loa Machinery Corporation, etc.) are hunted by MNCs. Some senior painting-workers of JP Auto2 were recruited from VEAM, whilst one of US Auto was poached from JP Auto2. US Auto's Regional Sales-andMarketing Manager used to work as another Japanese automotive-firm's equivalent. US FMCG2's Production-Manager used to work for JP FMCG. US Auto's HR-Manager used to work for JP Auto1. MNCs have become magnets for younger employees, who possess up-todate knowledge and technology, including those undergoing training and studying abroad. This trend leads to the domestic 'brain- drain' (O’Connor 1996; ITCT Staff 1999; Bonwick \& Associates 1999). Without the 'in-time' transformation and reform in HRM field, state-firms are losing their ability to compete against MNCs in their own country.

As far as the spillover effect is concerned, the important role of MNCs in managementtechnology of Vietnamese is indisputable. Domestic firms can observe foreign firms' 'bestpractices' and imitate them, which will result in production- and management-improvements. With competition, domestic firms are more likely to introduce new management-technologies earlier than would otherwise have been so. MNCs can, therefore, create spillover- effects 
through labour-turnover, when employees in MNCs decide to move to domestic firms or start their own SMEs (Blomstrom \& Kokko, 1996) or in the interactions with their Vietnamese partner in the joint-ventures (as in the case of US Auto, JP Auto1, JP Auto2). Le (2007) finds significant 'spillover-effects' in Vietnam during mid-1990s and early-2000s. This study concurs with these arguments. It points out the pressure of providing training to local staffmembers and a high turnover- rate confirm a 'spillover-effect' of training from foreigninvested sector to SOEs in the same industry. However, as noted by Ca (2009), the knowledge that SMEs and SOEs learnt from MNCs might be restricted to simple levels of production operations, whilst the learning and transferring of innovation knowledge (R\&D, design) may be limited.

\section{LIMITATIONS}

This research was, however, conducted within a finite timescale and is subject to limitations in both methodology and scope. First, it concentrates only on the US and Japanese subsidiaries of two industries. In general, it witnesses an attempt by corporations to transfer relatively constructive policies and practices. However, if the research had investigated more labour-intensive industries (textiles, footwear and so on) and/or corporations of different nationalities, especially those of, say, Hong Kong, South Korea and Taiwan, which are notorious for their cost-reduction strategies, it might have gained a different picture. Furthermore, by adopting a qualitative-method, this research does not rely on a large sample, as would occur with a survey-approach, and thus generalization to a large number of MNC subsidiaries is risky. However, we do hope that we have shed light on the transfer process of T\&D practices from US and Japanese MNCs to their Vietnamese subsidiaries and the current situation of $T \& D$ in these firms. 


\section{REFERENCES}

Ahmadjian CL and Robbins GE (2005) A clash of Capitalisms: Foreign shareholders and corporate restructuring in 1990s Japan. American Sociological Review 70 (3), 451-471.

Banks, LV (2004) Brick, Click: A Comparative Study on the Effectiveness of Content Delivery Modalities for Working Adults. Thesis (PhD). Touro University International.

Bartlett CA and Ghoshal S (1989) Managing across borders the transnational solution. Great Britain: Mackays of Chatham PLC, Chatham, Kent.

Beresford M (1988) Vietnam politics, economics and society. Great Britain: Pinter Publishers London and New York.

Bersin J (2004) The blended-learning book. Best-practices, proven methodologies, and lesson learned. Pfeiffer, San Francisco.

Birkinshaw J and Hood N (1998) Multinational subsidiary evolution: Capability and charter change in foreign-owned subsidiary corporations. Academy of Management Review 23(4), 773-795.

Björkman I and Yuan Lu (2001) Institutionalization and Bargaining Power Explanations of HRM Practices in International Joint-ventures: The Case of Chinese-Western Joint-ventures. Organization Studies 22(3), 491-512.

Björkman I, Fey, C and Park H (2007) Institutional theory and MNC subsidiary HRM practices: evidence from a three-country study. Journal of International Business Studies 38(3), 430-446. 
Blomstrom M and Kokko A (1996) How foreign investment affects host countries. World Bank Policy Research Working Paper No. 1745.

Bonwick \& Associates (1999) The employment practices of multinational companies in Vietnam (unpublished report).

Brewster C, Croucher R, Wood G and Brookes, M (2007) Collective and Individual Voice: Convergence in Europe?. International Journal of Human Resource Management 18 (7), $1246-1262$.

Ca NT (2009) Learning by networking with multinationals: A study of the Vietnamese automotive industry. In: M Graham and J Woo (eds) Fuelling economic growth: The role of public-private sector research in development. The UK: Practical Action Publishing Ltd.

Clarke I and Almond P (2004) Dynamism and embeddedness: towards a lower road? British subsidiaries of American multinationals. Industrial Relations Journal 35 (6): 536-556.

Collins, N. (2009) Economic Reform and Employment Relations in Vietnam, London and New York, NY, Routledge.

De Jong JA and Versloot B (1999) Structured on-the-job training: report of a multiple casestudy. International Journal of Training and Development 3(3), 186-199.

Dore R (1987) Taking Japan seriously: A Confucian perspective on leading economic issues. Stanford: Stanford University Press.

Dowling PJ, Welch DE and Schuler RS (1999) International human resource management: Managing people in a multinational context. Cincinnati: South-Western College Publishing. 
Doz YL and Prahalad CK (1984) Patterns of strategic control within multinational corporations. Journal of International Business Studies 15(2), 55-72.

Duoc TQ and Metzger C (2007) Quality of business graduates in Vietnamese institutions: multiple perspectives. The Journal of Management Development 26(7), 629-643.

Duong LB and Morgan WJ (2001) The Contribution of Vocational Education and Training to the Integration of Refugee Returnees in Vietnam. Compare: A journal of comparative education 31(1), 93-111.

Edwards PK, Ferner A and Sisson K (1993) People and the Process of Management in the Multinational Corporation: A Review and Some Illustrations. Working Papers, Warwick School of Industrial \& Business, http://econpapers.repec.org/RePEc:fth:warwin:43.

Eisenhardt KM (1989) Building theories from case study research. Academy of Management Review 14(4): 532-550.

Elger T and Smith C (1994) Global Japanization? Convergence and competition in the organization of the labour process. In: T Elger and C Smith, ed. Global Japanization? The transnational transformation of the labour process. London: Routledge, 31-59.

Farndale E, Brewster C and Poutsma E (2008) Coordinated vs. liberal market HRM: the impact of institutionalization on multinational firms. The International Journal of Human Resource Management 19 (11): 2004-2023.

Faulkner D, Pitkethly R and Child J (2002) International mergers and acquisitions in the UK 1985-94: a comparison of national HRM practices. International Journal of Human Resource Management 13(1): 106-122. 
Ferner A (1994) Multinational corporations and human resource management: An overview of research issues. Human Resource Management Journal 4(3), 79-102.

Ferner A (2000) The embeddedness of US multinational corporations in the US business system: implications for HR/IR. Occasional Papers No. 61. Leicester: De Montfort University Business School.

Ferner A and Edwards P (1995) Power and the diffusion of organizational change within multinational enterprises. European Journal of Industrial Relations 1(2), 229-257.

Ferner A and Quintanilla J (1998) Multinationals, national identity and the management of HRM: Anglo-saxonization and its limits. International Journal of Human Resource Management 9(4), 701-31.

Ferner A, Almond P and Colling T (2005) Institutional theory and the cross-national transfer of employment policy: the case of "workforce diversity" in US multinationals. Journal of International Business Studies. 36(3), 304-321.

Ferner A, Almond P, Clark I, Colling T, Edwards T, Holden L and Muller-Carmen M (2004) The dynamics of central control and subsidiary autonomy in the management of human resources: Case-study evidence from US MNCs in the UK. Organization Studies 25(3), 363391.

Ferner A, Almond P, Colling T and Edwards T (2005) Policies on Union Representation in US Multinationals in the UK: Between micro-politics and macro-institutions. British Journal of Industrial Relations 43 (4), 703-28. 
Ferner A, Quintanilla J and Varul MZ (2001) Country-of-origin effects, host-country effects and the management of HR in multinationals: German corporations in Britain and Spain. Journal of World Business. 36(1), 107-128.

Friedman J (2004) Firm Ownership and Internal Labor Practices in a Transition Economy: An Exploration of Worker Skill Acquisition in Vietnam. William Davidson Institute Working Papers Series 2004-696, William Davidson Institute at the University of Michigan.

Geib P (1999) U.S. strategic management in Vietnam's transition economy. Competitiveness Review. 9(1), 40-53.

Geppert M and Williams K (2006) Global, national and local practices in multinational corporations: towards a sociopolitical framework. The International Journal of Human Resource Management. 17(1), 49-69.

Giardini A, Kabst G and Müller-Camen M (2005) HRM in the German Business System. Management Revue 16 (1): 63 -80

Gunnigle P, Murphy K, Cleveland JN, Heraty N and Morley M (2002) Localization in human resource management: comparing American and European multinational corporations. Advances in International Management 14: 259-284.

Hall P and Soskice D (2001) An introduction to varieties of capitalism. In P Hall and D Soskice (eds) Varieties of capitalism: The institutional foundations of comparative advantage. Oxford: Oxford University Press, 1-70.

Hargreaves E, Montero C, Chau N, Sibli M and Thanh T (2001) Multigrade teaching in Peru, Sri Lanka and Vietnam: An overview. International Journal of Educational Development, 21(6), 499-520. 
Harry W and Nakajima C (2007) Ethnocentric HRM Policies in the Asia Pacific Region: An Explanation of Host-country Resistance. Management Revue. 18(4), 454-471.

Harzing A and Noorderhaven N (2009) Headquarters-subsidiary relationships and the country-of-origin effect. In EIBA (ed) New Perspectives in International Business Research (Progress In International Business Research, Volume 3). Emerald Group Publishing Limited, 13-40.

Hayden PM and Thiep LQ (2007) Institutional autonomy for higher education in Vietnam. Higher Education Research and Development. 26(1), 73-85

Hirst P and Thompson J (1999) Globalization in question. $2^{\text {nd }}$ edition. Cambridge: Polity Press.

Hollingsworth JR (1997) The institutional embeddedness of American capitalism. In C Crouch and W Streeck (eds) Political Economy of Modern Capitalism. London: Sage.

ICTC Staff (1999) Vietnam's manpower: Sources and issues. In VH Tran (ed) Sectoral Analysis Of Trade, Investment And Business In Vietnam. Great Britain: MacMillan Press Ltd.

King-Kauanui S, Ngoc SD and Ashley-Cotleur C (2006) Impact of human resource management: SME performance in Vietnam. Journal of Developmental Entrepreneurship. 11(1), 79-95.

Kono T and Clegg S (2001) Trends in Japanese management. Continuing strengths, current problems and changing priorities. London: Palgrave. 
Kostova T and Zaheer S (1999) Organizational legitimacy under conditions of complexity: the case of the multinational enterprise. Academy of Management Review. 24(1) 64-81.

Mackay S and Stockport G (2006) Blended-learning, classroom and E-learning. The Business Review 5(1), 82-88.

Maxwell JA (1996) Qualitative research design: an interactive approach. London : SAGE. McDaniel DO, Schermerhorn Jr JR and Cuoc HT (1999) Vietnam: the environment for management development in the twenty-first century. The Journal of Management Development. 18(1), 79-93

McGuire J and Dow S (2003) The persistence and implications of Japanese keiretsu organization. Journal of International Business Studies. 34(4), 374-388.

MOET [the Ministry of Education and Training] (1997) Tong ket va danh gia muoi nam doi moi giao duc va dao tao 1986-1996): Bao cao tong hop va chi tiet [Summarising and assessing the renovation of education and training in the 1986-1996 period, general and detailed report]. Hanoi, Vietnam.

MOET [the Ministry of Education and Training], 2006, Current Situation of Vietnamese Education, http://en.moet.gov.vn/?page=6.1\&view=3451, accessed on 20 January 2012. MOLISA [the Ministry of Labour, Invalids and Social Affairs] (2002) Statistical Yearbook of labour-invalids and social affairs 2002. Vietnam: Labour Social Publishing House.

MPI [the Ministry of Planning and Investment] (2006) Various internal documents collected at the Project Monitoring Department. MPI. Hanoi, Vietnam. 
Noble C (1997) The management of training in multinational corporations: Comparative case studies. Journal of European Industrial Training. 21 (Feb/March), 102-110

Nohria N and Ghoshal S (1997) The differentiated network. Organizing multinational corporations for value creation. San Francisco: Jossey-Bass Publishers.

Noorderhaven NG, Harzing AW (2003) The "country-of-origin effect" in multinational corporations: Sources, mechanisms and moderating conditions. Management International Review 43(2), 47-66.

O'Connor (1996) Labour market aspects of state enterprise reform in Vietnam. OECD Development Centre, Technical paper No. 117.

O'Sullivan M (2000) Contests for Corporate Control and Economic Performance in the United States and Germany. Oxford, Oxford University Press.

Ohmae K (1990) The borderless word. London: HarperCollins.

Orrù M (1997) The institutional analysis of capitalist economies. In M Orrù, NW Biggart and GG Hamilton (eds) The economic organization of East Asian capitalism. Thousand Oaks: SAGE Publications, 297-310.

Ouchi W (1981) Theory Z: how American business can meet the Japanese challenge.

Reading, Massachusetts: Addison-Wesley.

Pettigrew AM (1990) Longitudinal field research on change: theory and practice. Organisation Science 1(3): 267-291.

Poutsma E, Ligthart PEM and Veersma U (2006) The Diffusion of Calculative and Collaborative HRM Practices in European Firms. Industrial Relations 45(4), 513-546. 
Pucik V (1984) White-collar human resource management in large Japanese manufacturing firms. Human Resource Management 23(3), 257-276.

Pucik V and Hatvany N (1983) Management practices in Japan and their impact on business strategy. In R Lamb (ed) Advances in strategic management. Greenwich, CN: JAI Press, 103131.

Pudelko M, Harzing AWK. (2007) Country-of-Origin, Localization or Dominance Effect? An empirical investigation of HRM Practices in Foreign Subsidiaries. Human Resource Management 46(4), 535-559.

Rosenzweig PM and Singh JV (1991) Organizational environments and the multinational enterprise. Academy of Management Review 16(2), 340-361.

Rowley C and Benson J (2002) Convergence and divergence in Asian human resource management. Californian Management Review 44(2), 90-109.

Schuler RS and Jackson SE (2005) A Quarter-Century Review of Human Resource Management in the US: The Growth in Importance of the International Perspective. Management Review 16 (1): 11-35.

Scott WR (2001) Institutions and Organizations. 2nd edn. Thousand Oaks, CA: Sage Publications.

Smale A (2008) Global HRM integration: a knowledge transfer perspective. Personnel Review 37(2): 145-164.

Smith C and Meiksins P (1995) System, society and dominance effects in cross-national organizational analysis. Work, Employment \& Society 9(2), 241-267. 
Tan H and Lopez-Acevedo G (2003) Mexico: in-firm training for the knowledge economy. World Bank Policy Research Working Paper No. 2957. World Bank, Washington DC.

Thang NN and Buyens D (2008) Training Organizational Strategy \& Firm Performance. Asia Pacific Business Review 11(2), 176-183.

Thang NN and Quang T (2007) International briefing 18: training and development in Vietnam. International Journal of Training and Development 11(2), 139-149.

The Socialist Republic of Viet Nam (1992) Labour Law 1992.

The Socialist Republic of Viet Nam (1998) Education Law 1998.

Truong TQ and Swierczek FW (2009) Skills development in higher education in Vietnam. Asia Pacific Business Review 15(4), 565-586.

Van Smoorenburg, M.S.M. and Van der Velden, R.K.W. (2000), "The training of school leavers: complementarity or substitution?", Economics of Education Review, 19( 2): 207-17.

Vo A (2009) The transformation in the management of human resources and labour relations in Vietnam - an investigation into human resources and industrial relations policies and practices of multinationals and state-owned enterprises in Vietnam. Oxford: Chandos Publishing.

Vo A and Rowley C (2010) The internationalization of industrial relations? Japanese and US multinational corporations in Vietnam. Asia Pacific Business Review 16 (1 \& 2), 221 - 238.

Warner M (2002) Globalization, labour-markets and human resources in Asia Pacific economies: An overview. International Journal of Human Resource Management 13 (3): 384-398. 
Warner M (2003) (ed.) Culture and management in Asia. London and New York, NY:

RoutledgeCurzon.

Warner M (2011) (ed.) Confucianism HRM in Greater China; Theory and Practice. London and New York, NY: Routledge.

Warner M and Goodall K (2009) (eds) Management Training and Development in China:

Educating Managers in a Globalized Economy. London and New York, NY: Routledge.

Whitley R (1992) Societies, firms and markets: The social structuring of business systems. In R Whitley (ed.) European business systems firms and markets in their national contexts.

Thousand Oaks, CA: SAGE publications, 5-45.

Whitley R (1999) How and why are international firms different? The consequences of crossborder managerial coordination for firm characteristics and behavior. Paper presented to Sub theme 3 "Business System In Their International Context" of the 15th EGOS Colloquium, University of Warwick, 4th - 6th July 1999.

Whitley R (2000) Divergent capitalisms the social structuring and change of business systems. Oxford: Oxford University Press.

World Bank (2005) Country Classification-Data and statistics.

http://web.worldbank.org/wbsite/external/datastatistics/0,,contentmdk:20420458 menupk:64 133156 pagepk:64133150 pipk:64133175 thesitepk:239419,00.html. Accessed on 2 March 2010.

World Bank (2011) Country Classification -Data and statistics. http://ddpext.worldbank.org/ext/ddpreports/ . Accessed on 2 Jan 2012. 
Yan Y (2003) A comparative study of human resource management practices in international joint-ventures: the impact of national origin. International Journal of Human Resource Management 14(4): 487-510.

Yin RK (2009) Case-study Research: Design and Methods. 4th edn. London, England: Sage Publications.

Yu J and Meyer-Ohle H (2008) Working for Japanese Corporations in China: A Qualitative Study. Asian Business \& Management 7(1): 33-52. 